\title{
Monetary and financial integration in EU: Convergence or divergence?
}

\author{
Larysa Sysoyeva
}

Ph.D., Research Fellow, Alfried Krupp Wissenschaftskolleg, Greifswald, Germany

\begin{abstract}
This study explores the analysis of convergence process of EU countries. The analysis shall proceed through three steps. Firstly, we shall describe our position within the theoretical discourse about convergence theory. Then we shall move on to compare the indicators of monetary and fiscal discipline in select EU Member States. Thirdly, we shall analyse whether a convergence of financial development takes place within the group of European countries.
\end{abstract}

Keywords: monetary integration, financial integration, convergence.

JEL Classification: E42, F15, F36.

DOI: $10.21272 /$ fmir.1(2).5-11.2017.

(C) The Author, 2017. This article is published with open access at ARMG Publishing.

\section{Introduction}

The main objective of European economic integration is to align the indicators of economic development of all EU member states, to create equal competitive conditions and opportunities, to increase productivity and living standards. It is this unprecedented expansion of the EU from May, 12004 to January, 12007 that showed new horizons for the economic development of Eastern European countries and prompted them to integrate into a single monetary, currency and banking space. The so-called "fifth wave of EU enlargement" was associated with great hopes and expectations, first of all, for the new EU countries, including the former Soviet republics, since such step allowed for not only a systemic transformation in the countries of Eastern Europe but also construction of qualitatively new functioning market system as a necessary component of a democratic society.

The convergence process is the subject of numerous analyzes in terms of economic parameters convergence of regions to a certain level. But convergence within the EU countries in recent years has changed for a divergence on indicators of fiscal discipline, wage income and profitability in capital markets. The global economic crisis of 2008 has caused some important issues in monetary policy. It turned too that the post-crisis period showed that constant financial stability is the main goal of the implemented actions in the context of global disturbances in financial sectors. Thus, at present the issue of convergence processes regarding the indicators of monetary and financial development within the EU member states is actualized.

\section{Literature review}

In the theoretical discussion on the definition of the term "convergence" basic approaches are differentiated. As Barros (1991) different countries have the same preferences and technology, given the existence of decreasing marginal returns in the use of accumulating factors, especially capital, poor countries tend to grow faster than rich ones. Each country would attain its own steady state but, in the meantime, its differences in per capita income would tend to diminish. So, this theory predicts a process of catching-up (conditional convergence). Another possible solution can be observed when rich and poor countries reach the same steady state of income level, which forms the strict definition of convergence (absolute or unconditional). Quah and Durlauf (1999) argue that a world with economies tending towards either the very rich or very poor, with the middle-income classes vanishing. The results of studies indicate that the majority of countries and regions have become much richer during the past century, but those that have already been richer have gained considerably more. Therefore the gap between rich and poor ones has increased. Authors of the New Economic Geography (see Krugman et all 1991) assert, that “... location is playing an important role in economic activity of the region". So poor regions have greater chances for development if they are surrounded by the rich neighbours (see also Le Gallo 2001). 
In terms of growth convergence is defined as the equalization of various regional economies into a single path of economic growth. According to these criteria there are three well-known competitive convergence hypotheses: the absolute convergence hypothesis, according to which the per capita incomes of countries or regions with one another in the long-term regardless of the initial conditions. Thus, it provides the homogeneity of regions and the presence of a single path of growth. Conditional convergence provides the existence of fundamental differences and irresistible heterogeneity for convergence in the countries.

Finally, representatives of the club convergence hypothesis argue that the country's location plays an important role in the economic activity of the region. In addition to other factors the economic situation in the region depends on its location, as well as on its neighbors. Poor regions are more likely to develop if they are surrounded by rich neighbors. A group of countries can come closer to a particular balance only in the long-term perspective if there are structural mismatches and the initial conditions for economic and social development are heterogeneous. The study of the convergence incomes in the world over the past 200 years allowed Dowrick and Delong (2001) to distinguish four periods that are shifting towards income convergence or divergence.

According to their research there was no convergence of economic development in the second half of the 20th century. The overall inequality between countries has increased, convergence occurs only in small groups of economies, for countries such as the OECD after the Second World War (see Dowrick and Nguyen 1989) in the Easten Asia after 1960 . The regions of India at the end of the 20th century (see Bajpai and Sachs, 2000). These examples are given in accordance with the hypothesis of club convergence.

\section{Methods}

Our study will focus on the question whether convergence within the EU-28 group occurs. For this purpose we will examine the process of club convergence on the example of indicators of monetary development and development of the financial sector within the group of European countries.

According to the Lisbon Treaty, the primary objective of the Central Bank is to maintain price stability. There can also be transferred specific functions to the central bank related to the prudential supervision of credit institutions ${ }^{1}$.

At the Copenhagen Summit held in June 1993, it was stressed that it was necessary for the countries that demanded the EU membership to meet certain criteria. These criteria, known as the Copenhagen Criteria, consisted of political, economic, and legislative groups:

$>$ Political: the candidate country, besides showing respect to the state of law, human rights, and minority rights, was also required to have an organisational structure that guarantees democracy

$>$ Economic: a functioning market economy and the capacity to cope with the competitive structure in the EU were required

$>$ Legislative: fulfilling the responsibilities of membership in accordance with the objectives of the political, economic, and monetary community.

It should be noted that the Maastricht Treaty signed on February 7, 1992 determined that for the successful functioning of the Monetary and Monetary Union of the EU it is extremely important for member states to achieve a high degree of sustainable convergence in the form of low inflation, strong public finances and stable rate of the national currency. Thus, countries that are going to join Monetary Union have to correspond so-called "convergence criteria" which were formulated in Maastricht Treaty. In accordance with the Maastricht Treaty, a country that is a member of the EU has to fulfil "convergence criteria" in order to enter the monetary union. Reaching a certain level of development is among the necessary conditions for a member country. The following criteria (see Table 1) were determined to provide price stability, fiscal discipline and monetary discipline by the Maastricht Treaty. Thus, countries that are at the stage of joining the Monetary union must meet the so-called "convergence criteria", which were formulated in the Maastricht Treaty.

${ }^{1}$ Artikel 127, Absatz 6 des Vertrages von Lissabon, http://www.europarl.europa.eu/aboutparliament/de/20150201PVL00008/Der-Vrertag-von-Lissabon. 
Table 1. Maastricht criteria and descriptions

\begin{tabular}{|l|l|l|}
\hline \multicolumn{1}{|c|}{ Criteria } & \multicolumn{1}{c|}{ Indicator } & \multicolumn{1}{c|}{ Description } \\
\hline Inflation Rate & $\begin{array}{l}\text { The annual average inflation rate should be above } \\
1.5 \% \text { of the three members of the EU with the } \\
\text { lowest inflation rates }\end{array}$ & For price stability \\
\hline Budget Deficit/GDP Ratio & $3 \%$ & For fiscal discipline \\
\hline Public Debt/GDP Ratio & $60 \%$ & For fiscal discipline \\
\hline Interest Rate & average int. rate +2 point & For monetary discipline \\
\hline Exchange Rate & $\begin{array}{l}\text { The national currency's fluctuation limit should } \\
\text { not exceed }(+/-) 15 \text { without devaluation }\end{array}$ & For monetary discipline \\
\hline
\end{tabular}

If the Copenhagen criteria determine the country's ability to join the EU, the fulfillment of the Maastricht criteria is a prerequisite for the country's accession to the European Economic and Monetary Union. The decision to bring the country closer to the Monetary Union is formed on the basis of the main provisions of the annual reports of the European Commission and the ECB. It analyzes both the individual economic indicators of the country's fragmentation and the general tendencies of the main monetary indicators to identify the dynamics of convergence processes.

At the first stage we will analyze whether the level of development of indicators of monetary integration is converging according to the ECB reports. The indicators of economic convergence are analyzed by European Central Bank and are published on ECB site. In the next table indicators that were determined to provide price stability, fiscal discipline and monetary discipline by the Maastricht Treaty for countries of euro-zone and countries that have to introduce euro next years, namely - Bulgaria, Czech Republic, Croatia, Hungary, Poland and Sweden are presented. In the table data for Great Britain and Denmark are not included. Denmark has got special release of Maastricht Treaty.

Table 2. Overview table of economic indicators of convergence during 2012-2016, \%

\begin{tabular}{|c|c|c|c|c|}
\hline & Year & Inflation & $\begin{array}{c}\text { General government } \\
\text { debt }\end{array}$ & $\begin{array}{l}\text { Long-term } \\
\text { interest rate }\end{array}$ \\
\hline EU-19 & $\begin{array}{l}2012 \\
2013 \\
2014 \\
2015 \\
2016\end{array}$ & $\begin{array}{l}2.5 \\
1.4 \\
0.2 \\
0.0 \\
0.2\end{array}$ & $\begin{array}{r}89.5 \\
91.4 \\
92.0 \\
90.3 \\
89.2 \\
\end{array}$ & $\begin{array}{l}3.9 \\
3.0 \\
2.0 \\
1.2 \\
0.9 \\
\end{array}$ \\
\hline EU-7 & $\begin{array}{l}2012 \\
2013 \\
2014 \\
2015 \\
2016\end{array}$ & $\begin{array}{c}3.8 \\
1.7 \\
0.1 \\
-0.2 \\
-0.2\end{array}$ & $\begin{array}{l}55.4 \\
57.9 \\
61.3 \\
60.5 \\
60.6\end{array}$ & $\begin{array}{l}5.8 \\
4.6 \\
3.9 \\
2.8 \\
2.9\end{array}$ \\
\hline Reference value* & & 0.7 & 60.0 & 4.0 \\
\hline
\end{tabular}

Notes: * The reference values for inflation and long-term interest rates refer to the period from May 2015 to April 2016.

Source: ECB. Authors calculations.

As it is shown in the table the dynamics of inflation rate has been achieved both in the countries of the euro area and in the countries which only have to introduce the euro. Thus, for example, in Romania in 2016 deflation was at $1.3 \%$. Reductions in budget imbalances were observed in all countries. With regard to the convergence of longterm interest rates, all seven countries under review recorded, long-term interest rates below the reference value, which was $4 \%$. The lowest interest rates were in Sweden at the level 0.8\% and Czech Republic - 0.6\%.

At the second stage we will study the convergence of indicators that characterize financial sector, namely: the Bank deposits to GDP, the Z-score, the NPL and also a number of indicators with financial market development (8 pillars) of the Global Competitiveness Annual Report.

Many methods for convergence have been developed by scientists, among them: Markov chains, probabilistic approach, time series analysis, matrix method and others. It is the matrix method we will use in our study which foresees the analysis of the matrix of transition probabilities. In all cases of our calculations we will primarily 
determine the fluctuation of the indicator (the gap between the maximum and minimum). Then we are going to divide into three levels according to the degree of development of a certain indicator (high, middle and low) allocating proportional groups. And then, with the help of matrix method of base minor we will estimate probability whether the country (group of countries) has a chance to move to another group, as well as to estimate how many times and what groups investigated countries performed the transition. For a so-called unit matrix (MDETERM = 1) there will be a situation where all remain in their groups and there are no transitions. The stability of the existing clubs by the level of the indicator will be considered for the probability of transition to another group less than 5\%. The Determinante of the matrix less than 0.0625 means that we have a chaotic situation and a situation where the formation of clubs is impossible. Due to the non-uniform level of the development and infrastructure of banking sectors the $28 \mathrm{EU}$ members are grouped based on the EU accession principle - the old European states (EU-15 minus UK) and new member states (EU-13).

\section{Results}

The Indicator Bank deposits to GDP (\%) is determined by the World bank as Demand, time and saving deposits in deposit money banks - as a share of GDP. Data for 2000-2014 are presented for EU-28 countries except United Kingdom. The number of transitions between groups (Bank deposits to GDP: "high" > 100\%, "middle" - 50-100\%, "low" $-<50 \%)$ and the matrix of transition probabilities is presented in Tables 3 and 4.

Table 3. Matrix of transition of the indicator bank deposits to GDP (\%) for EU-28

\begin{tabular}{|l|l|c|c|c|c|}
\hline \multicolumn{2}{|c|}{} & \multicolumn{3}{|c|}{ Output states } & $\begin{array}{c}\text { The number of input states in } \\
\text { a cluster }\end{array}$ \\
\cline { 2 - 6 } \multicolumn{2}{|c|}{} & High & Middle & Low & \\
\hline \multirow{3}{*}{ Input states } & High & 39 & 2 & 0 & 41 \\
\cline { 2 - 6 } & Middle & 4 & 175 & 3 & 182 \\
\cline { 2 - 6 } & Low & 0 & 12 & 89 & 101 \\
\hline \multicolumn{2}{|l|}{ Number of output states in the group } & 43 & 189 & 92 & 324 \\
\hline
\end{tabular}

Table 4. The matrix of transition probabilities of the indicator bank deposits to GDP (\%) for EU-28

\begin{tabular}{|l|l|c|c|c|c|}
\hline \multicolumn{2}{|c|}{} & \multicolumn{3}{|c|}{ Output states } & \multirow{2}{*}{ Sum } \\
\cline { 3 - 6 } \multicolumn{2}{c|}{} & High & Middle & Low & \\
\hline \multirow{3}{*}{ Input states } & High & 0.9512 & 0.0488 & 0 & 1 \\
\cline { 2 - 6 } & Middle & 0.0220 & 0.9615 & 0.0165 & 1 \\
\cline { 2 - 6 } & Low & 0 & 0.1188 & 0.8812 & 1 \\
\hline
\end{tabular}

Three countries had the high level in 2000 and kept it throughout the entire period (Cyprus, Luxembourg and Malta). In the countries with the middle level at the very beginning of the period (Austria, Belgium, Czech Republic, France, Germany, Ireland, Netherlands, Portugal, Slovak Republic and Spain) 2 of them moved to the high level (Belgium and Netherlands) and 1 - to the low level (Slovak Republic). 14 countries with the low level at the beginning of the period moved to the middle level in the majority except those 4 that kept their level without any changes (Hungary, Latvia, Lithuania and Romania). For the entire period of 2000-2014 for the EU-28 countries MDETERM $=0.8032$, that means that there is a sustainability according to the level Bank deposits to GDP and countries almost do not change their status.

The next indicator is the so-called Z-score, the indicator of financial stability. The choice is based on the following reasons: first of all this indicator is recognized by the World Bank as a measure of the stability of the banking system. Secondly, we follow Anginer et al. (2012), Demirgüc-Kunt and Detragiache (2011), Čihák and Hesse (2007) and use the Z-score as a rough measure of systemic soundness. Thirdly, the individual bank's Z-score is widely used as a measure of bank distance to default (Boyd and Runkle (1993), Beck and Laeven (2006), Laeven and Levine (2009).

It is assumed that the 'average' level is within $\pm 50 \%$ of the mean value, while the lower and higher Z-score values will be termed 'low' and 'high' accordingly. The average level of Z-score in the group of EU-28 countries is 8.9. 
We have analyzed the number of transitions for the period of 1996-2013 for EU countries, i.e. the total number of transitions: 16 years $* 28$ countries $=448$. The states in EU-15 in the period prior to the crisis (2004-2008) had a high level of financial stability in the banking sector. However, the world financial crisis significantly reduced the level of financial stability in the European banking sector, as reflected in the reduction of the Z-score indicator. In the period with the crisis (2008-2014) in most EU-15 countries, namely in Belgium, France, Germany, Ireland, Luxembourg, Netherlands, Portugal, Spain, Sweden, and the United Kingdom the banking sector shows a gradual restoring to their level of financial stability. Transition table looks like this.

Table 5. Matrix of transition of the indicator Z-score for EU-28

\begin{tabular}{|l|l|c|c|c|c|}
\hline \multicolumn{2}{|c|}{} & \multicolumn{3}{|c|}{ Output states } & $\begin{array}{c}\text { The number of input states in a } \\
\text { cluster }\end{array}$ \\
\cline { 3 - 6 } \multicolumn{2}{|c|}{} & High & Middle & Low & \\
\hline \multirow{3}{*}{ Input states } & High & 89 & 22 & 0 & 111 \\
\cline { 2 - 6 } & Middle & 24 & 132 & 23 & 179 \\
\cline { 2 - 6 } & Low & 0 & 23 & 135 & 158 \\
\hline \multicolumn{2}{|c|}{ Number of output states in the group } & 113 & 177 & 158 & 448 \\
\hline
\end{tabular}

High level during the whole period saved Austria, Germany, Luxembourg and Slovak Republic; Low level Bulgaria, Cyprus, Czech Republic, Greece, Hungary, Latvia and Lithuania. Only Romania increased its level.

Table 6. The matrix of transition probabilities of the indicator Z-score for EU-28

\begin{tabular}{|c|c|c|c|c|c|}
\hline & \multicolumn{3}{|c|}{ Output states } & \multirow{2}{*}{ Sum } \\
\hline & & High & Middle & Low & \\
\hline \multirow{3}{*}{ Input states } & High & 0.8018 & 0.1982 & 0 & 1 \\
\hline & Middle & 0.1341 & 0.7374 & 0.1285 & 1 \\
\hline & Low & 0 & 0.1456 & 0.8544 & 1 \\
\hline
\end{tabular}

For the whole period of 1996-2014 for EU-28 countries MDETERM=0.4675 and it means that there is an average group convergence according to Z-score level.

One more indicator is the Bank nonperforming loans to gross loans (NPL, (\%). Data are presented for the EU-28 countries for the period of 2000-2014 except for 2001-2002. Group level is determined as "high" > 9\%, "middle" - 3$9 \%$, "low" - <3\%) and the matrix of transition probabilities is presented in following table.

Table 7. Matrix of transition of the indicator Bank nonperforming loans to gross loans (\%) for EU-28

\begin{tabular}{|l|c|c|c|c|c|}
\hline \multicolumn{2}{|c|}{} & \multicolumn{3}{|c|}{ Output states } & \multirow{2}{*}{$\begin{array}{c}\text { The number of input states in } \\
\text { a cluster }\end{array}$} \\
\cline { 2 - 5 } & High & High & Middle & Low & 57 \\
\hline \multirow{3}{*}{ Input states } & Middle & 11 & 9 & 1 & 126 \\
\cline { 2 - 5 } & Low & 2 & 100 & 15 & 153 \\
\hline \multicolumn{2}{|c|}{ Number of output states in the group } & 60 & 130 & 146 & 336 \\
\hline
\end{tabular}

The high level of the NPL was in 2000 in 7 countries (Bulgaria, Croatia, Czech Republic, Greece, Lithuania, Poland and Slovak Republic) and at the end of the period it remained only in three of them (Bulgaria, Croatia and Greece). In all other countries the level changes were too dynamic and there were transitions in different directions both improvement (Czech Republic and Poland) and deterioration (Hungary, Ireland and Portugal).

Table 8. The matrix of transition probabilities of the indicator Bank nonperforming loans to gross loans, $(\%)$ for EU-28

\begin{tabular}{|c|c|c|c|c|c|}
\hline & \multicolumn{3}{|c|}{ Output states } & \multirow{2}{*}{ Sum } \\
\hline & & High & Middle & Low & \\
\hline \multirow{3}{*}{ Input states } & High & 0.8246 & 0.1579 & 0.0175 & 1 \\
\hline & Middle & 0.0873 & 0.7937 & 0.1190 & 1 \\
\hline & Low & 0 & 0 & 1 & 1 \\
\hline
\end{tabular}


For the entire period for EU-28 countries MDETERM $=0.5311$ and it means that there is an average group convergence according to NPL level.

Further we continue to analyze financial indicators: with Financial market development from the $8^{\text {th }}$ pillar of the Global Competitiveness Annual Report that are calculated and are made public on the website of the World Economic Forum): Financial market sophistication, Financing through local equity market, Ease of access to loans, Venture capital availability, Soundness of banks, Regulation of securities exchanges, Legal rights index.

Evaluation results of MDETERM according to the matrix of transition probabilities are given in Table 9.

Table 9. MDETERM according to the matrix of transition probabilities of EU-28

\begin{tabular}{|c|c|}
\hline & MDETERM \\
\hline Bank deposits to GDP (\%) & 0.8032 \\
\hline Z-score & 0.4675 \\
\hline NPL - Bank nonperforming loans to gross loans (\%) & 0.5311 \\
\hline Financial market sophistication / Availability of financial services & 0.5108 \\
\hline Financing through local equity market & 0.4447 \\
\hline Ease of access to loans & 0.6102 \\
\hline Venture capital availability & 0.4933 \\
\hline Soundness of banks & 0.5940 \\
\hline Regulation of securities exchanges & 0.4869 \\
\hline Legal rights index & 0.7106 \\
\hline 8 pillar - Financial market development & 0.4951 \\
\hline
\end{tabular}

Thus, (High, Middle and Low) groups are the steadiest according to the indicators of the Bank deposits to GDP (\%) and the Legal rights index. The convergence is practically not observed there. But regarding to other indicators there is a certain convergence. For example, as to the Soundness of banks indicator: the majority of the countries has the middle level and two of them decreased their status to the low level (Cyprus, Greece). Countries with the high level by Soundness of banks indicator - constantly vary in their status (nearly every country from Low to High), since during the research period the global crisis happened. Also, the volatility of existing groups is observed and, consequently, convergence according to the main indicators of financial market development Financial market sophistication, Financing through local equity market, Ease of access to loans, Venture capital availability, Regulation of securities exchanges.

\section{Conclusion}

The convergence and integration of European economies with European Union is undoubtedly one of Europe's success stories. In most countries further progress has been made with regard to the dynamics of the most important indicators of the financial convergence (similarity of interest rates, inflationary convergence and fiscal integration). However, continued convergence may be more challenging due to various factors. The individual countries still have significant vulnerabilities of various kinds, particularly in the banking sector. The financial crisis encouraged the countries to improve efficiency of their banking sectors. The implementation of that approach in EU countries has been reflected in the banking union formation, the introduction of more stringent regulatory requirements for certain banks, bank merger and acquisition procedures in accordance with the Basel Committee on Banking Supervision recommendations.

\section{References}

1. Anginer, Deniz, Demirgüç-Kunt, Asli, and Min Zhu (2012). How Does Bank Competition Affect Systemic Stability? World Bank Policy Research Paper 5981.

2. Barro, Robert J. (1991). Economic Growth in a Cross Section of Countries. Quarterly Journal of Economics, 106(2), 407-443.

3. Bajpai, Nirupam, and Jeffrey D. Sachs (2000). Foreign Direct Investment in India: Issues and problems. Development Discussion Paper No. 759. 
4. Beck, Thorsten, and Luc Laeven (2006). Resolution of Failed Banks by Deposit Insurers: CrossCountry Evidence. Unpublished. Washington: World Bank.

5. Boyd, John H., and David E. Runkle (1993). Size and Performance of Banking Firms. Journal of Monetary Economics, 31, 47-67.

6. Demirgüç-Kunt, Asli, and Enrica Detragiache (2011)."Basel Core Principles and Bank Soundness: Does compliance matter? Journal of Financial Stability, 7(4), 179-190.

7. Durlauf, Steven, and Danny T. Quah (1999). The new empirics of economic growth. Handbook of Macroeconomics, in: J. B. Taylor \& M. Woodford (ed.), Handbook of Macroeconomics, ed. 1, No 1 (4), 235-308.

8. Dowrick, Steve, and J. Bradford DeLong (2001). Globalisation and Convergence. Retrieved from www.jbradforddelong.net/Econ_Articles/Dowrick/GandC.PDF.

9. Dowrick, Steve, and Duc-Tho Nguyen (1989). OECD Comparative Economic Growth 1950-85: Catch-Up and Convergence. American Economic Review, 79, 1010-1030.

10. European Central Bank (2016). Convergence Report June 2016. Frankfurt/M. (ECB). Retrieved from https://www.ecb.europa.eu/pub/pdf/conrep/cr201606.en.pdf?a91977931874a7c6c63d80305b651394.

11. European Central Bank (2014). Convergence Report June 2016. Frankfurt/M. (ECB). Retrieved from https://www.ecb.europa.eu/pub/pdf/conrep/cr201406en.pdf?c759d9b132af38d2cde1900f23c35ce9.

12. European Commission. Accession criteria. Retrieved from https://ec.europa.eu/neighbourhood-enlargement/policy/glossary/terms/accession-criteria.

13. European Commission. The Treaty on European Union, signed at Maastricht on 7 February 1992, Title-VII, Article 121. Retrieved from http://eur-lex.europa.eu/collection/eu-law/treaties.html.

14. Hesse, Heiko, and Martin Čihák (2007). Cooperative Banks and Financial Stability. Unpublished. International Monetary Fund Working Paper 07/02.

15. Krugman, Paul (1991). Increasing Returns and Economic Geography. Journal of Political Economy, 99, 483-499.

16. Laeven, Luc, and Ross Levine (2009). Bank governance, regulation and risk taking. Journal of Financial Economics, 93(2), 259-275.

17. Le Gallo, Julie (2004). Space-Time Analysis of GDP Disparities among European Regions: A Markov Chains Approach. International Regional Science Review, 27(2), 138-163.

18. The World Economic Forum. The Global Competitiveness Annual Report in 2006-2016. Retrieved from https://www.weforum.org/reports. 